\title{
Anatomy of stem and root of Ipomoea cairica (L.) Sweet (Convolvulaceae) - the Lianescent Vascular Syndrome
}

\author{
Mailson Santos Martins ${ }^{1}$, Maria Lenise da Silva Guedes ${ }^{2}$, Claudia Luizon Dias Leme ${ }^{3}$
}

\begin{abstract}
Resumo. Anatomia de caule e raíz de Ipomoea cairica (L.) Sweet (Convolvulaceae) - a Síndrome Vascular Lianescente. Entre as espécies de Ipomoea de importância econômica, a liana Ipomoea cairica se destaca por grande potencial farmacológico. Considerando que a variação cambial presente em Ipomoea não está diretamente relacionada ao hábito, o presente estudo tem como objetivo listar o grupo de características anatômicas que definem a Síndrome Vascular Lianescente na espécie, assim como verificar se existe variação entre o lenho do caule e da raiz. Secções transversais e longitudinais de material fresco foram analisadas qualitativa e quantitativamente. Assim, verificou-se que a anatomia da madeira de I. cairica é semelhante à de outras espécies de Ipomoea, incluindo xilema secundário com anéis de crescimento indistintos e vasos com porosidade difusa, principalmente solitários, placa de perfuração simples, pontoações areoladas alternas, tiloses, raios heterocelulares, principalmente uniseriados e a presença de raios não lignificados. As características da "síndrome vascular lianescente" estão relacionadas ao vaso dimorfismo e à alta porcentagem de parênquima. Entretanto, análise estatística mostrou diferenças no diâmetro de vasos, com valores maiores, e frequência de vasos, com valores mais baixos, para as raízes. Essas diferenças devem estar relacionadas ao ambiente em que o órgão se desenvolve, assim como com os mecanismos envolvidos na condução hídrica. Estudos específicos possibilitarão testar esta hipótese.
\end{abstract}

Palavras-chave: câmbios sucessivos, dimorfismo dos vasos, drusas, glória da manhã, parênquima não lignificado, variação cambial.

\begin{abstract}
Anatomy of stem and root of Ipomoea cairica (L.) Sweet (Convolvulaceae) - the Lianescent Vascular Syndrome. Among the Ipomoea species of economic importance, the liana Ipomoea cairica stands out because of its great pharmacological potential. Considering that the cambial variant present in Ipomoea is not causally related to the habit, the aim of this study is to list the group of anatomical features that define the "lianescent vascular syndrome" in the species, as well as to verify if there is variation between the stem and the root anatomy. Transverse and longitudinal sections of fresh material were analyzed qualitatively and quantitatively. Thus, it was found that the anatomy of the secondary xylem of I. cairica is similar to that of other species of Ipomoea, including indistinct growth rings, diffuse and porous vessels mainly solitary, simple perforation plate, alternate bordered pit, tyloses, heterocellular mainly uniseriate rays, and non-lignified parenchyma. The characteristics of the "lianescent vascular syndrome" is related to the high percentage of parenchyma. However, statistical analysis showed differences between stem and root in vessel diameter and vessel frequency, with higher values of vessel diameter and lower values of frequency of vessels in the root secondary xylem. These differences must be related to the environment in which the organ develops, as well as to the mechanisms involved in water conduction. Specific studies will make possible to test this hypothesis.

Key words: cambial variant, climbers, druses, morning glory, secondary xylem, successive cambia; unlignified parenchyma.
\end{abstract}

Ipomoea L., with 600-700 species, is one of the largest and most diverse genera of the Convolvulaceae family (Austin 1975, Austin 1998, Austin \& Huáman 1996, Stefanovic et al. 2003).
The genus consists of herbaceous, liananescent and climbing plants, and a small group of shrubs and trees that occurs mainly in South and Central America, and in Tropical Africa (Austin 1980,

Accepted on February 9, 2021.

${ }^{1}$ Universidade Federal da Bahia (UFBA), Rua Barão de Jeremoabo, 668. CEP: 40170-115. E-mail: ylsonmartins@gmail.com (author for correspondence).

${ }^{2}$ Universidade Federal da Bahia (UFBA), Rua Barão de Jeremoabo, 668. CEP: 40170-115. E-mail: mlguedes2003@yahoo.com.br

${ }^{3}$ Universidade Federal de São Paulo (Unifesp), Rua Prof. Artur Riedel, 275, CEP 09972-270. E-mail: clauleme09@gmail.com 
Austin \& Huáman 1996). In Brazil there are about 149 species of Ipomoea, 80 of which occur in the Northeast region (Flora do Brazil 2018).

Regardless of the habit, species of the genus Ipomea generally present some type of cambial variant, characterized by the presence of successive cambium and inter or intraxylemic phloem (Bhambie 1972, Lowell \& Lucansky 1986, Lowell \& Lucansky 1990, Carlquist \& Hanson 1991, McDonald 1992, Rajput et al. 2008, Patil et al. 2009, Ceja-Romero \& PérezOlvera 2010, Terrazas et al. 2011, Rajput et al. $2014 \mathrm{a}, \mathrm{b})$. The stem wood anatomy of some species of Ipomoea has been previously described and studies on the cambial variant development have been carried out, such as the contributions of Patil et al. (2009) and Rajput et al. (2013) with Ipomoea hederfolia L., Rajput et al. (2014b) with I. pes-caprae (L.) R. Br., Delbon et al. (2016) with I. cairica (L.) Sweet, I. purpurea (L.) Roth and I. rubriflora O'Donell, and Rajput (2017) and Rajput \& Gondaliya (2017) with I. turbinata Lag.

Among the species of Ipomoea, of economic importance, the liana $I$. cairica, internationally known as morning-glory, and in Brazil, popularly called jetirana, jitirama and ipomea stands out. Although known as an invasive species in China and other countries (Geng et al. 2016), I. cairica has great pharmacological potential, having been mentioned as a promising medicinal plant due to its antifungal, antimicrobial, anti-inflammatory, antioxidant action, in addition to of its anti-tumor and anti-hypoglycemic properties (Ferreira et al. 2006, Meira et al. 2012, Choudhury et al. 2015, Srivastava \& Shukla 2015a, 2015b, Zuharah et al., 2016, Dantas et al. 2019).

According to Delbon et al. (2016) and Yang (2020), I. cairica has two types of cambial variant, the lobed pattern, and successive/multiple cambia. Delbon et al. (2016) inferred that in Ipomoea the type of secondary growth, as well as the cambial variant types, would not be related to the habit.

A combination of anatomical features has been used to characterize lianas, termed as 'lianescent vascular syndrome' by Angyalossy et al. (2015). Thus, the present study aimed to investigate the set of wood anatomical feature that would define the "lianescent vascular syndrome" in I. cairica, and if there is any structural variation in the secondary xylem that could differentiate the root from the stem of $I$. cairica.

\section{Material and Methods}

The study took place at the Federal University of Bahia, Salvador, Bahia Brazil. Stem and root samples from three adult individuals of Ipomoea cairica were collected in Salvador (lat. 12.966667 long.38.51083) and deposited in the herbaria Alexandre Leal Costa (ALCB 113235) at the Federal University of Bahia. Stem samples were taken, considering the thicker portions of the stem (at $1.30 \mathrm{~m}$ from the soil level), and root samples at $10-20 \mathrm{~cm}$ from the base of the stem.

Transversal and longitudinal sections (radial and tangential) of fresh material were cut by hand, using a single-edged razor blade. The freehand sections were diaphanized in $50 \%$ sodium hypochlorite, rinsed in distilled water, and stained in Astra Blue and Safranin according to the modified technique of Kraus \& Arduin (1997). Semipermanent slides were mounted in $50 \%$ glycerin.

The wood anatomy description followed the determinations of the IAWA Committee (1989). For quantitative analysis it was considered the vessel diameter and frequency, number of solitary vessels, and ray width and length in number of cells. Measurements were made using the Image Pro-Express 6.0 analysis program, with an Infinity 1 camera coupled to an Olympus $3 \times 31$ optical microscope. Significant differences in measured characteristics between stem and root were detected by applying the Student's t test for each sample using a statistical software (Excel 2013, Microsoft).

\section{Results}

The unequal deposition of the secondary xylem and the formation of successive cambium result in a different conformation of the stem and root with concentric rings of xylem, phloem, and connective tissue, as shown in figure 1.

The secondary xylem anatomy of the stem and root of $I$. cairica is described below and showed on figures 2 and 3.

Growth rings are indistinct on the stem and root. The vessels have diffuse porosity with $80-90 \%$ of the large-caliber vessels predominantly solitary and occasionally small-caliber vessels (10-20\%) on the stem and root, the perforation plate is simple and the intervessel pits alternate and areolated. The tangential average diameter of the vessels is $162.9 \mu \mathrm{m}$ on the stem and $220.3 \mu \mathrm{m}$ on the root, and the average frequency is 15.8 vessels per $\mathrm{mm}^{2}$ 
on the stem and 11.1 vessels per $\mathrm{mm}^{2}$ on the root, of these, 12.6 vessels per $\mathrm{mm}^{2}$ are solitary on the stem and 9.8 vessels per $\mathrm{mm}^{2}$ on the root. The average length of the vessels is $113.3 \mu \mathrm{m}$ on the stem and $157.3 \mu \mathrm{m}$ on the root. Frequent tyloses are observed. Fibrotracheids are present with an average length of $413.3 \mu \mathrm{m}$ on the stem and 356.7 $\mu \mathrm{m}$ on the root, libriform fibers are also observed. The axial parenchyma is mainly vasicentric and occasionally forming narrow bands, with parenchyma series composed of an average of 3 cells, with thin walls, and little or no lignification. The rays are heterocellular, composed mostly of square and upright cells; predominantly uniseriate in the stem with an average width of $29.5 \mu \mathrm{m}$, and predominantly biseriate in the root with an average width of $30 \mu \mathrm{m}$ (not including the large rays). The ray average height is of $366,2 \mu \mathrm{m}$ and 8.8 cells in the stem, and a minimum height of $706.6 \mu \mathrm{m}$ and 7.5 cells at the root. Large multiseriate rays, not lignified, are present with a concentration of druses in some areas (Fig. 2 and 3).

The results for the quantitative analysis show that the differences between stem and root, regardless vessel diameter and vessel frequency were considered statistically significant (P-values $<0.005)$.

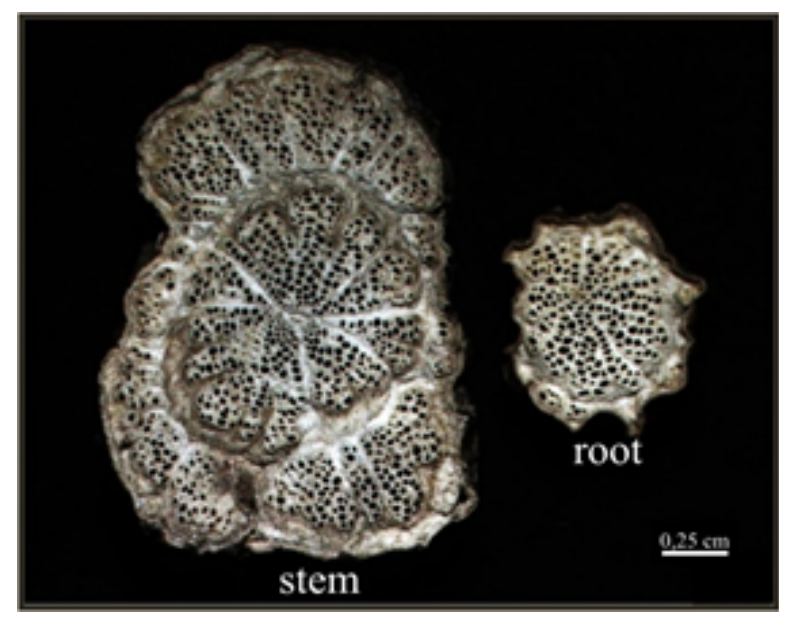

Figure 1. Stem and root cross-sections of Ipomoea cairica (Convolvulaceae). The stem present larger diameter and successive cambial with production of more secondary xylem.

\section{Discussion}

The characteristic that would describe the "lianescent vascular syndrome" in Ipomoea cairica is the high percentage of parenchyma. Add to that, the differences between the organs are exclusively quantitative, related to the diameter and frequency of the vessels.

The stem and root of I. cairica presented similar conformation, with lobed pattern and successive/ multiple cambia, corroborating the observations of the stem and root of I. hederiflora and I. quamoclit by Lowell \& Lucansky (1986, 1990), and for the stem of I. cairica by Delbón et al. (2016) and Yang et al. (2020). Chen et al. (2007) worked with very young stems of $I$. cairica, where the presence of cambial variations was not evident, as observed in the images of the manuscript.

Authors such as Lowell \& Lucansky (1990), Carlquist (2007) and Angyalossy et al. (2012) emphasize the asymmetry in the stem of vines is associated with the habit, with the way the vine is in contact with the plant that supports it. However, Delbon et al. (2016), in the study with I. cairica, I. purpurea and I. rubriflora, linoid species, and I. carnea, arboreal species, infer that the type of secondary growth and the type of cambial variation are not directly related to the habit, since, according to Carlquist \& Hanson (1991), the tree species of Ipomoea also have successive cambia, which leads to consider the action of genetic and hormonal regulation in the development of the cambial variation in the studied species (Sorce et al. 2013; Ursache et al. 2013).

The secondary xylem anatomy of I. cairica is similar to the Ipomoea species described in the literature, as for I. hederifolia and I. pres-caprae by Rajput et al. (2008, 2014), I. arborescens, I. chilopsidis, I. intrapilosa, I. murucoides, I. pauciflora, I. populina, I. rzedowskii and I. wolcottiana, Ipomoea described by Ceja-Romero \& Pérez-Olvera (2010), and for I. cairica by Terrazas et al. (2011), where the authors mention with indistinct growth rings, diffuse and porous secondary xylem with mostly solitary vessels, simple perforation plates, alternate areolated intervessel pits, uniseriate rays and non-lignified parenchyma.

The qualitative characteristics of the secondary xylem did not vary between the stem and root of Ipomoea cairica, corroborating the comparative studies of Lowell \& Lucansky (1986, 1990), which describe the anatomy of young stems and roots of I. hederifolia and I. quamocit. However, significant quantitative differences observed between the stem and the root in relation to the diameter and frequency of the vessels, which may reveal responses of the xylem secondary to the 
environment in which the stem and root develop. Furthermore, considering that the diameters of the vessels increase from the apex of the young stems towards the base, following the law of hydraulic conductivity potential (Anfodillo et al.
2006, Olson et al. 2014), it is well justified that larger vessels in the roots would contribute to the increase in hydraulic efficiency (Ewers et al. 1997, Loepfe et al. 2007, Zach 2010).
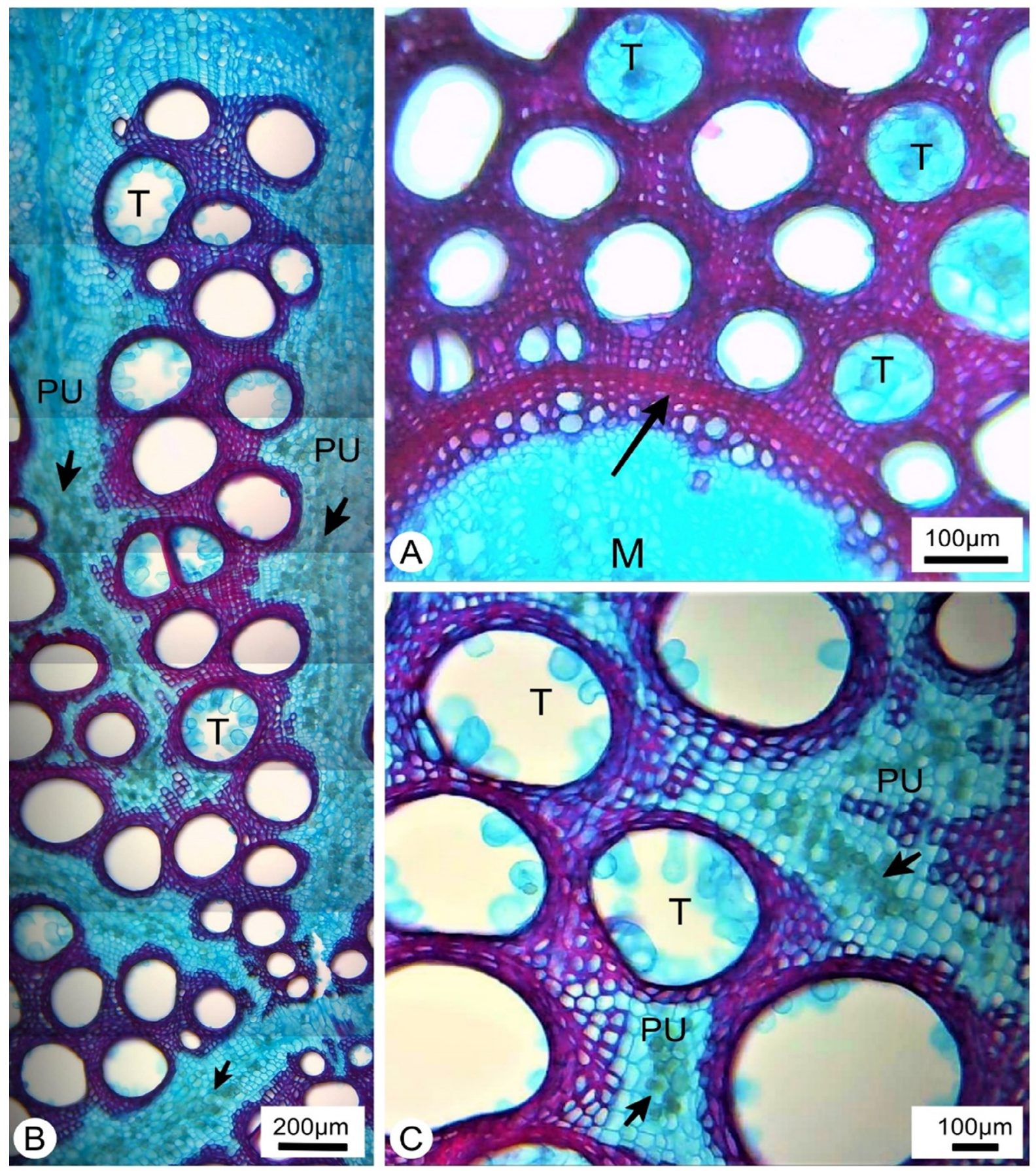

Figure 2. Transverse section of Ipomoea cairica. A. Stem with a tick walled cells (arrow) close to the pith (M) followed by the secondary xylem composed of wide vessels with tylose (T). B. Root with parenchyma unlignified (PU) forming large rays with druses (arrow) and wide vessels with tyloses (T). C. Detail of the axial parenchyma unlignified with druses, parenchyma lignified thick walled, vasicentric, forming narrow bands. 
The quantitative results for I. cairica, although they corroborate those of Machado et al. (1997), Psaras \& Sofroniou (2004) and Goulart (2016), who observed greater diameter of vessels in the roots when compared to the stem of trees in different species / families, disagree with the studies of Cutler (1976), Dias-Leme (1994) and Esemann-Quadros (2001) where the authors show similarities in the vessel diameter of the stem and root. Critically, the literature shows most of the wood anatomy studies the wood features have not been statistically analyzed, and clearly confirm the care that should be taken with the generalization about the differences between stem and root, as already mentioned by Cutler (1976), where, to the frequency of vessels between the stem and the root, in his own works, the author found variation in the results, finding stem and root with similar for some species and different for others.

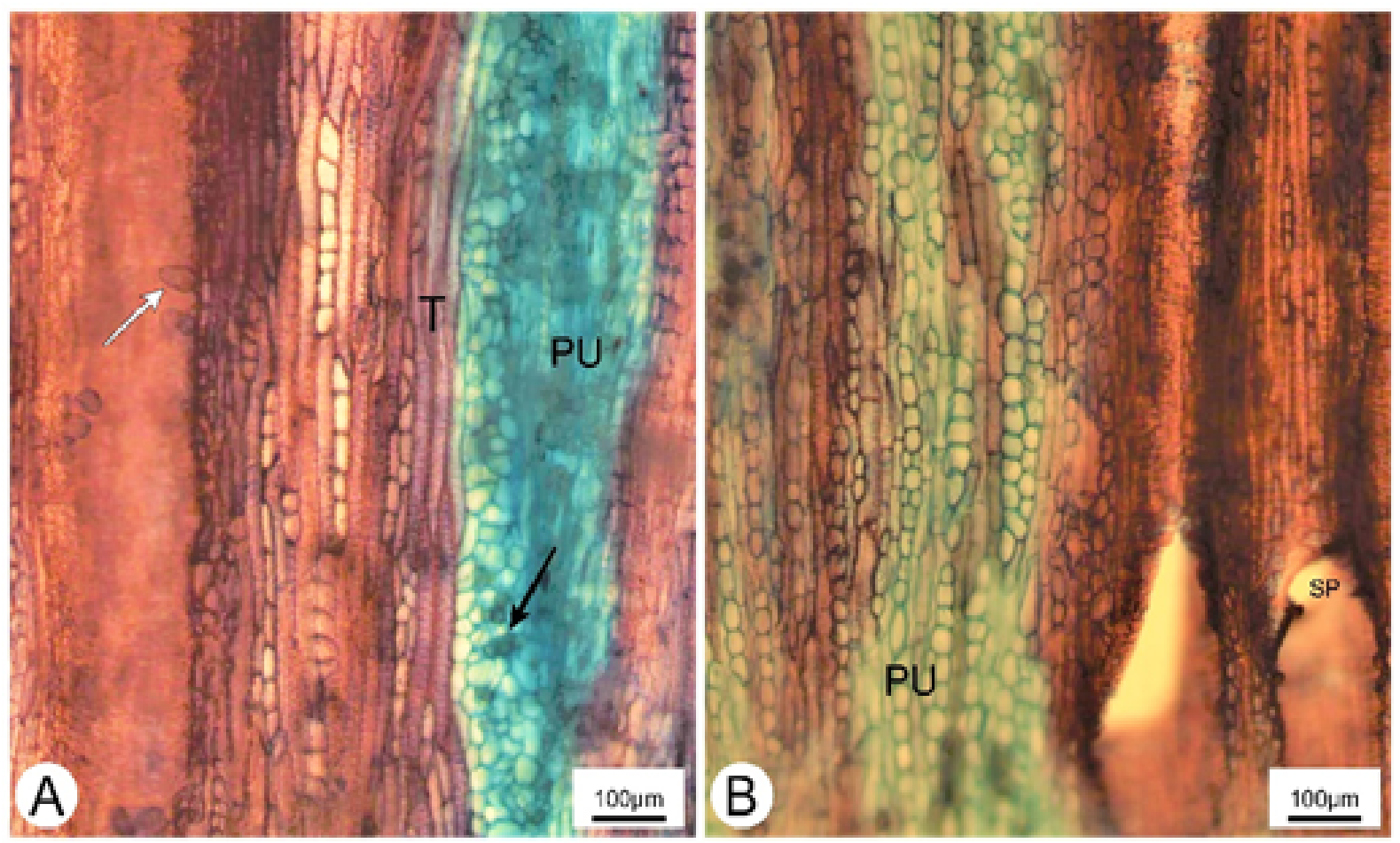

Figure 3. Longitudinal tangential section of Ipomoea cairica. A. Stem. Rays uniseriate, parenchyma unlignified - large rays (PU) with druses (black arrow), vessels with tylose (white arrow), tracheids (T). B. Root. Rays uniseriate and bisseriate, parenchyma unlignified - axial and radial (PU), vessel with simple perforation plate (SP).

Large rays and abundant axial parenchyma were observed in stems and roots of I. cairica. The abundance in the parenchyma provides greater flexibility and facilitates the liana growth to reach distant/higher places (Delbón et al. 2016). In $I$. cairica, the cambial variant produces abundant parenchyma between the bands of vascular tissue, which would support what was postulated by Mc Donald (1992). Accord to McDonald (1992), the presence of cambium multiple in trees of Ipomoea is a derived character that arose from a climber ancestor with typical secondary growth. For that said, the cambial variant is not included in this case as a feature of the "lianescent vascular syndrome", but just high percentage of parenchyma in the secondary xylem.

\section{Conclusion}

Ipomoea cairica showed similar qualitative anatomical characteristics in the comparison between stem and root, and as for the "lianescent vascular syndrome", stem and root showed a high proportion of parenchyma. However, statistical analysis showed significant differences for the diameter and frequency of the vessels that differentiate the stem from the root, and these differences may be related to the environment in which the organ develops, as well as to the mechanisms involved in water conduction. Specific studies will allow to test these hypotheses. 


\section{Acknowledgements}

The authors are grateful to Museu de Zoologia at the Federal University of Bahia for the use of the image analysis equipment, and the "Projeto Permanecer"- Federal University of Bahia for the Scientific Initiation scholarship granted to the first author.

\section{References}

Anfodillo, T., G. Petit \& A. Crivellaro. 2013. Axial conduit widening in woody species: a still neglected anatomical pattern. In: Wood Structure in Plant Biology and Ecology: 24-36.

Angyalossy, V., G. Angeles, M.R. Pace, A.C. Lima, C.L. Dias-Leme, L.G. Lohmann \& C. Madero-Vega. 2012. An overview of the anatomy, development and evolution of the vascular system of lianas. Plant Ecology \& Diversity 5 (2): 167-182.

Angyalossy, V., M.R. Pace \& A.C. Lima. 2015. Liana anatomy: a broad perspective on structural evolution of the vascular system. Ecology of lianas: 253-287.

Austin, D.F. 1975. Typification of the new world subdivisions of Ipomoea L. (Convolvulaceae). Taxon 24:107-110.

Austin, D.F. 1980. Additional comments on infrageneric taxa in Ipomoea (Convolvulaceae). Taxon 29: 501-502.

Austin, D.F. 1998. Convolvulaceae morning glory family. Journal of the Arizona-Nevada Academy of Science: 6183.

Austin, D.F. \& Z. Huáman. 1996. A synopsis of Ipomoea (Convolvulaceae) in the Americas. Taxon 63 (3): 3-38.

Bhambie, S. 1972. Correlation between form, structure and habit in some lianas. In: Proceedings of the Indian Academy of Sciences-Section B. Springer India: 246256.

Carlberg, C. 2014. Statistical analysis: Microsoft excel 2013. Que Publishing.

Carlquist, S. 2007. Successive cambia revisited: ontogeny, histology, diversity, and functional significance. The Journal of the Torrey Botanical Society 134 (2): 301-332.

Carlquist, S., M.A. Hanson. 1991. Wood and Stem Anatomy of Convolvulaceae. Aliso: A Journal of Systematic and Evolutionary Botany 13: 51-94.

Ceja-Romero, J. \& C. de la P. Perez-Oliveira. 2010. Wood anatomy of the arboreal species of Ipomoea (Convolvulaceae). Madera y Bosques 16: 61-73.

Chen, D., Y. Ding, R. Ma, H. Zhu \& A. Lu. 2007. Anatomical structure of stem of Ipomoea cairica (Convolvulaceae). Acta Botanica Yunnanica 2: 189-192.

Choudhury, S., C.H. Rahaman \& S. Mandal. 2015. Studies on Ipomoea Cairica (L.) Sweet-A Promising Ethnomedicinally Important Plant. Journal of Innovations in Pharmaceuticals and Biological Sciences 2: 378-395.

Cutler, D.F. 1976. Variation in root wood anatomy. Leiden Botanical Series 3: 143-156.

Dantas, J.O., T.G. Araújo-Piovezan, D.P. Santos, A.E.O. Alves, S.S.C. Pinheiro \& G.T. Ribeiro. 2019. Extracts of Potential Plants in the Control of the Aedes aegypti Population. Ensaios e Ciência: Ciências Biológicas, Agrárias e da Saúde 23: 104-108.

Delbón, N., Sánchez, A. \& M.T. Cosa. 2016. Variante cambial en tallos de Ipomoea (Convolvulaceae) nativas de Argentina. Boletín de la Sociedad Argentina de Botánica, v. 51, p. 635-642.

Dias-Leme, C.L. 1994. Anatomia comparada do lenho do caule, raiz e ramo de algumas espécies de Euphorbiaceae da Mata Atlântica. Master theses (Dissertação de Mestrado em Botânica) Universidade de São Paulo, São Paulo. 70pp.

Esemann-Quadros, K. 2001. Anatomia do lenho de Clusia criuva Camb.(Clusiaceae): órgãos, hábitos e ambientes. $\mathrm{PhD}$ dissertation (Tese de Doutorado em Botânica), Universidade de São Paulo, São Paulo). 132pp.

Ewers, F.W., M.R. Carlton, J.B. Fisher, K.J. Kolb \& M.T. Tyree. 1997. Vessel diameters in roots versus stems of tropical lianas and other growth forms. Iawa Journal 18: 261-279.

Ferreira, A.A., F.A. Amaral, I.D.G. Duarte, P.M. Oliveira, R.B. Alves, D. Silveira \& M.S.A. Castro. 2006. Antinociceptive effect from Ipomoea cairica extract. Journal of Ethnopharmacology 1051: 48-153.

Geng, Y., L. Chen, H. Lu, C. Ning, L.O. Björn \& S. Li. 2016. Metabolic characteristics of invasive plant Ipomoea cairica in South China by de novo transcriptomics. Journal ofTropical and Subtropical Botany 24: 128-142.

Goulart, S.L. Compared anatomy of root and stem wood of Aegiphila sellowiana Cham. (Verbenaceae). 2016. Cerne, v. 18 , p. $595-606$.

Goulart, S.L. \& C.R. Marcati. 2008. Anatomia comparada do lenho em raiz e caule de Lippia salviifolia Cham. (Verbenaceae). Brazilian Journal of Botany 31: 263-275.

IAWA Committee. 1989. IAWA list of microscopic features for hardwood identification. IAWA Bull. (ns) 10: 219-332.

Kraus, J.E. \& M. Arduin. 1997. Manual básico de métodos em morfologia vegetal. Rio de Janeiro, EDUR. 198pp.

Loepfe, L., J. Martinez-Vilalta, J. Pinol, M. Mencuccini. 2007. The relevance of xylem network structure for plant hydraulic efficiency and safety. Journal of Theoretical Biology 247: 788-803.

Lowell, C. \& T.W. Lucansky. 1986. Vegetative anatomy and morphology of Ipomoea hederifolia (Convolvulaceae). Bulletin of the Torrey Botanical Club 113: 382-397.

Lowell, C. \& T.W. Lucansky. 1990. Vegetative anatomy and morphology of Ipomoea quamoclit (Convolvulaceae). Bulletin of the Torrey Botanical Club 117: 232-246.

Machado, S.R., V. Angyalossy-Alfonso \& B.L. de Morretes. 1997. Comparative wood anatomy of root and stem in Styrax camporum (Styracaceae). IAWA Journal 18: 1325.

Mcdonald, J.A. 1992. Evolutionary implications of typical and anomalous secondary growth in arborescent Ipomoea (Convolvulaceae). Bulletin of the Torrey Botanical Club 119: 262-267

Meira, M., E.P.D.Silva, J.M. David \& J.P. David. 2012. Review of the genus Ipomoea: traditional uses, chemistry and biological activities. Revista Brasileira de Farmacognosia 22: 682-713.

Olson, M.E., T. Anfodillo, J.A. Rosell, G. Petit, A. Crivellaro, S. Isnard \& M. Castorena. 2014. Universal hydraulics of the flowering plants: vessel diameter scales with stem length across angiosperm lineages, habits and climates. Ecology Letters 17: 988-997.

Patil, V.S., K.S. Rao \& K.S. Rajput. 2009. Development of intraxylary phloem and internal cambium in Ipomoea hederifolia (Convolvulaceae). The Journal of the Torrey Botanical Society 136: 423-432. 
Martins, M.S., M.L. Guedes \& C.L. Leme, Anatomy of stem and root of Ipomoea cairica.

Psaras, G.K. \& I. Sofroniou. 2004. Stem and root wood anatomy of the shrub Phlomis fruticosa (Labiatae). IAWA Journal 25: 71-77.

Rajput, K.S. 2017. Development of Inverse Cambia and Structure of Secondary Xylem in Ipomoea turbinata (Convolvulaceae). Polish Botanical Journal 62: 87-97.

Rajput, K.S. \& A.D. Gondaliya. 2017. Internal cambium and intraxylary phloem development in Ipomoea turbinata Lag. (Convolvulaceae). Flora 226: 47-54.

Rajput, K.S., B.D. Chaudhary \& V.S. Patil. 2014a. Development of successive cambia and structure of secondary xylem of Ipomoea obscura (Convolvulaceae). Polish Botanical Journal 59: 55-61.

Rajput, K.S., V.S. Patil \& K.S. Rao. 2014b. Multiple cambia and secondary xylem of Ipomoea pes-caprae (L.) R. Br. (Convolvulaceae). Acta Botanica Gallica 161: 13-19.

Rajput, K.S., V.S. Patil \& K.S. Rao. 2013. Wood Anatomy and the Development of Interxylary Phloem of Ipomoea hederifolia Linn. (Convolvulaceae). Journal of Plant Growth Regulation 32: 654-662.

Rajput, K.S., V.M. Raole \& D. Gandhi. 2008. Radial secondary growth and formation of successive cambia and their products in Ipomoea hederifolia L. (Convolvulaceae). Botanical journal of the Linnean Society 158: 30-40.

Rajput, K. S., V. S. Patil \& K. S. Rao. 2013. Wood anatomy and the development of interxylary phloem of Ipomoea hederifolia Linn. (Convolvulaceae). Journal of Plant Growth Regulation 32: 654-662.

Simão-Bianchini, R., P.P.A. Ferreira \& L.V. Vasconcelos. 2020. Ipomoea in Flora do Brasil 2020 em construção. Jardim Botânico do Rio de Janeiro.Disponível em: Available at: http://floradobrasil.jbrj.gov.br/reflora/ floradobrasil/FB7030 (acessed: February 2021)

Sorce, C., A. Giovannelli, L. Sebastiani \& T. Anfodillo. 2013. Hormonal signals involved in the regulation of cambial activity, xylogenesis and vessel patterning in trees. Plant Cell Reports 32: 885-898.
Srivastava, D. \& K. Shukla. 2015a. Antioxidant potential of medicinal plant Ipomoea cairica (L) Sweet. International Journal of Development Research 5: 4255-4258.

Srivastava, D. \& K. Shukla. 2015b. Ipomoea cairica: a medicinal weed with promising health benefits. International Journal of Information Research and Review 2: 687-694.

Stefanović, S., D.F. Austin \& R.G. Olmstead. 2003. Classification of Convolvulaceae: a phylogenetic approach. Systematic Botany 28: 791-806.

Terrazas, T., S. Aguilar-Rodríguez \& C.T. Ojanguren. 2011. Development of successive cambia, cambial activity, and their relationship to physiological traits in Ipomoea arborescens (Convolvulaceae) seedlings. American Journal of Botany 98: 765-774.

Ursache, R., K. Nieminen \& Y. Helariutta. 2013. Genetic and hormonal regulation of cambial development. Physiologia Plantarum 147: 36-45.

Yang, S.Z., P.H. Chen \& C.F. Chen. 2020. Cambial Variants Combine Successive Cambia and Intraxylary Phloem in Convolvulaceae in Taiwan. American Journal of Plant Sciences 11: 437-453.

Zach, A., B. Schuldt, S. Brix, V. Horna, H. Culmsee \& C. Leuschner. 2010. Vessel diameter and xylem hydraulic conductivity increase with tree height in tropical rainforest trees in Sulawesi, Indonesia. Flora-Morphology, Distribution, Functional Ecology of Plants 205: 506-512.

Zuharah, W.F., R. Ahbirami, H. Dieng, M. Thiagaletchumi $\&$ N. Fadzly. 2016. Evaluation of sublethal effects of Ipomoea cairica Linn. Extract on life history traits of dengue vectors. Revista do Instituto de Medicina Tropical de São Paulo: 58. 